\title{
Research Article \\ MOLECULAR DETECTION AND CHARACTERIZATION OF COAT PROTEIN GENE OF MUNGBEAN YELLOW MOSAIC VIRUS (MYMV) FROM KARNATAKA
}

\author{
PREMA G. U. ${ }^{*}$ AND RANGASWAMY K.T. ${ }^{2}$ \\ ${ }^{1}$ Department of Plant Pathology, College of Agriculture, Vijaypur, 586101, University of Agricultural Sciences, Dharwad, 580005, Karnataka \\ 2Department of Plant Pathology, College of Agriculture, University of Agricultural Sciences, GKVK, Bangalore, 560065, Karnataka \\ *Corresponding Author: Email-prems.gu@gmail.com
}

Received: January 30, 2018; Revised: February 07, 2018; Accepted: February 08, 2018; Published: February 15, 2018

\begin{abstract}
Mungbean yellow mosaic disease is a major constraint in production of mungbean in Karnataka. An expected band size of approximately 1000 bp was amplified from MYMV-CP-F/MYMV-CP-R primers, designed specifically for MYMV. Mungbean yellow mosaic virus (MYMV) was characterized by sequencing the coat protein gene. The actual length of MYMV obtained was 889 bp including 115 bp pre-coat proteins at 5' end, 774 bp core coat protein and 257 deduced amino acids. The phylogenetic analysis of the coat protein sequence of yellow mosaic virus infecting mungbean was carried out together with the known begomoviruses sequences obtained from Genbank database. Cluster phylogram based comparison of the coding nucleotide sequences of MYMV-Hebbal-Bangalore isolate revealed that the MYMV-Hebbal, Bangalore isolate group with cluster II consisting of Mungbean yellow mosaic viruses. Analysis of nucleotide sequence of coat protein gene of yellow mosaic virus associated with mungbean showed maximum identity with 99\% MYMV-Maharashtra: SB [AF314530.1], followed by 98.9\% with MYMV-Namakka I: MoB [DQ865201.1] as well as MYMV-Tamil Nadu:MB [AJ132575.1] and 98.8\% with MYMV-Madurai: SB isolates [AJ421642.1]. The nucleotide identity of MYMV-Hebbal isolate with other MYMV isolates ranged between 94.5-99\%. MYMV-Hebbal, Bangalore isolate showed an identity of 79.3-81.0\% with different MYMIV isolates. The amino acid sequence of mungbean yellow mosaic virus shared maximum identity of about 100\% with MYMV-Maharashtra: SB [AF314530.1], MYMV-Tamil Nadu:MB [AJ132575.1], 99.6\% with MYMV-Namakkal:MoB [DQ865201.1], 99.2\% with MYMV-Madurai: SB [AJ421642.1]. The deduced amino acid identity of MYMV-HebbalBangalore isolate with other MYMV isolates ranged between $96.4-100 \%$. The aminoacid identity of MYMV-Hebbal-Bangalore isolate with other MYMIV isolates ranged from $84.0-85.9 \%$. The results from the present study revealed that yellow mosaic virus infecting mungbean from Hebbal, Bangalore is a Mungbean yellow mosaic virus (MYMV) but not Mungbean yellow mosaic India virus(MYMIV) and is a variant of Mungbean yellow mosaic virus(MYMV).
\end{abstract}

Keywords- Mungbean yellow mosaic virus (MYMV), Coat protein, Detection, Characterization, Phylogenetic analysis, Nucleotide sequence identity, Amino acid identity

Citation: Prema G. U. and Rangaswamy K.T. (2018) Molecular Detection and Characterization of Coat Protein Gene of Mungbean Yellow Mosaic Virus (MYMV) from Karnataka. International Journal of Agriculture Sciences, ISSN: 0975-3710 \& E-ISSN: 0975-9107, Volume 10, Issue 3, pp.-5118-5122.

DOI: http://dx.doi.org/10.9735/0975-3710.10.3.5118-5122

Copyright: Copyright@2018 Prema, G. U. and Rangaswamy K.T. This is an open-access article distributed under the terms of the Creative Commons Attribution License, which permits unrestricted use, distribution and reproduction in any medium, provided the original author and source are credited.

\section{Introduction}

Mungbean or Greengram [Vigna radiata (L.) Wilczek], is one of the food legumes grown in India. It is native to India and Central Asia. It consists of $23.6 \%$ of easily digestible protein and $51 \%$ carbohydrates. It is cultivated in China, Thailand, the Philippines, Vietnam, Indonesia, Myanmar, Bangladesh, India and in the hot and dry regions of Southern Europe and Southern United States [1]. It fixes biological nitrogen ranging from $30-74 \mathrm{~kg} / \mathrm{ha}$ in the soil and also provides plant residues (1520 quintals/ ha). Plants are also used for making green manures.

In India, mungbean is grown in an area of 33.87 lakh ha, with a production of 16.34 lakh tonnes and productivity of $483 \mathrm{~kg} / \mathrm{ha}$. The major mungbean producing states in India are Andhra Pradesh, Karnataka, Tamil Nadu, Maharashtra, Madhya Pradesh, Gujarat, Rajasthan and Orissa.

In Karnataka, the total area under mungbean is 2.93 lakh ha, giving a total production of 0.73 lakh tonnes, with an average productivity of $249 \mathrm{~kg} / \mathrm{ha}$. The major districts of Karnataka cultivating mungbean are Tumkur, Chickmagalur, Hassan, Shimoga, Mysore, Davanagere, Chitradurga, Mandya, Bidar, Kalaburagi and Yadgir[2].

The diseases affecting mungbean are cercospora leaf spot ( $C$. canescens, $C$. cruenta), powdery mildew (Erysiphe polygoni), root disease complex (Pythium spp, Rhizoctonia solani, Fusarium spp.). Mungbean yellow mosaic virus disease
(MYMV) is the most damaging viral disease which was first reported from New Delhi in 1960. MYMV belongs to genus Begomovirus and family Geminiviridae [3]. It is transmitted mainly by whitefly, Bemisia tabaci (Genn.) in a circulative manner [4]. The virus has geminate particles $(20 \times 30 \mathrm{~nm})$ with spherical, single stranded DNA fragment of $2.8 \mathrm{~Kb}$ [5]. The disease can even be transmitted by grafting but sap, seed or soil transmission is not seen [6]. The disease incidence ranged from 31.49 to 100 per cent in Southern Karnataka [7]. The virus inoculum is contributed by numerous alternate hosts of the virus and the whitefly vector, which help in rapid spread of the disease [8].The characteristic symptoms of YMV on mungbean include irregular green and yellow patches in older leaves and complete yellowing of younger leaves. Fewer flowers and pods are produced by the infected plants. Pods of the affected plants often develop mottling, remain small and contain fewer and smaller seeds thus reducing the yield drastically $[9,10]$.

According to earlier reports, mungbean is affected by both Mungbean Yellow Mosaic Virus (MYMV) and Mungbean Yellow Mosaic India Virus (MYMIV). So, the investigations were carried out to prove that yellow mosaic virus infecting mungbean from Karnataka is an isolate of Mungbean yellow mosaic virus (MYMV) rather than Mungbean Yellow Mosaic India Virus (MYMIV). At present literature is available on the per cent disease incidence, epidemiology, virus-vector relationships, transmission, sources of resistance to MYMV and integrated 
disease management practices $[4,6,7,11-24]$. But the information at genomic level is not available for MYMV from Karnataka. The information on phylogenetic relationships of MYMV with other YMV isolates associated with other grain legumes are also not available. Hence, the present study has been taken up to characterize coat protein gene of MYMV infecting mungbean from Karnataka.

\section{Material and Methods}

\section{Sample collection}

Mungbean plants showing severe yellow mosaic and mottling symptoms were collected from field at the MRS, Hebbal, Bangalore, Karnataka during the 2012 [Plate-1]. Samples from healthy plants were collected as controls.

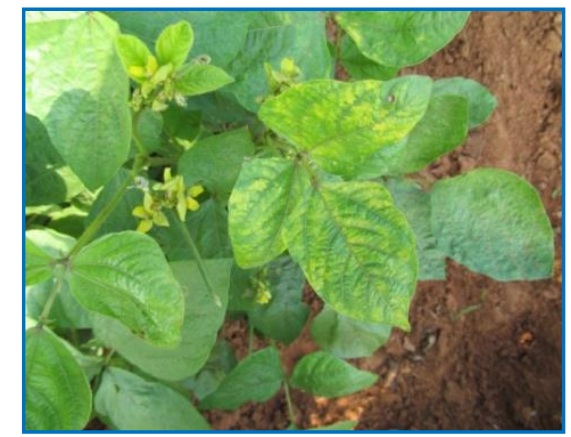

Plate-1 Mungbean plants showing typical symptoms of yellow mosaic virus

\section{Nucleic acid extraction}

The total genomic DNA was extracted from leaf tissues of healthy mungbean plants and YMV infected mungbean plants based on modified CTAB method [25]. One hundred and fifty milligrams of fresh YMV infected leaf tissues were ground with liquid nitrogen using sterile pestle and mortar. The whole ground sample was transferred into a fresh 1.5 -ml eppendorf tube. $1500 \mu$ l of pre-warmed $\left(65^{\circ} \mathrm{C}\right)$ DNA extraction buffer was added to ground sample taken in 1.5-ml eppendorf tube (added in situ just before DNA extraction). The whole crude sap was incubated for $30 \mathrm{~min}$ at $60^{\circ} \mathrm{C}$ in a water bath with occasional mixing. The supernatant $(750 \mu \mathrm{l})$ was transferred into a fresh 1.5-ml effendorf tube and mixed with equal amount $(750 \mu \mathrm{l})$ of Phenol: chloroform: isoamyl alcohol (25: 24:1) by vertexing. The samples were then centrifuged at 13,000 rpm for 10 min using micro centrifuge. The aqueous supernatant was collected in to a fresh $1.5-\mathrm{ml}$ eppendorf tube. The DNA was precipitated by mixing with $300 \mu$ of chilled isopropanol $+30 \mu l$ of $7.5 \mathrm{M}$ Ammonium acetate by inversion. The tubes were centrifuged at $13,000 \mathrm{rpm}$ for 10 min. The resulted pellet was washed with 70 per cent ethanol, dried in a vacuum drier for $10 \mathrm{~min}$ and re-suspended with $40 \mu \mathrm{l}$ of $\mathrm{T}_{10} \mathrm{E}_{0.1}$ buffer $(10 \mathrm{mM}$ Tris- $\mathrm{HCl}$ of $\mathrm{pH} 8.0$ and $0.1 \mathrm{mM}$ EDTA of $\mathrm{pH} 8.0$ ) and stored at $-20^{\circ} \mathrm{C}$. All the DNA extracts were further diluted from 1:10 to 1:40 in single distilled water (SDW) before using for PCR amplifications. The quality and quantity of DNA was assessed at $260 \mathrm{~nm}$ and $280 \mathrm{~nm}$ using UV spectrophotometer.

\section{Primers used, PCR amplification and gel electrophoresis}

In order to determine the nucleotide sequence of coat protein of mungbean yellow mosaic virus, specific primers available in the literature were tried to amplify coat protein region of yellow mosaic viruses of nearly $1000 \mathrm{bp}$. Primers specific to MYMV (MYMV-CP-F-ATG GG (T/G) TCC GTT GTA TGC TTG /MYMV-CP-RGGC GTC ATT AGC ATA GGC AAT) were used for amplification of coat protein gene of mungbean yellow mosaic virus (MYMV). Primers were designed to get the complete coat protein gene of yellow mosaic viruses of legume hosts by taking 100 extra nucleotides on both the sides of the gene [26].

PCR was performed in Thermocycler (Eppendorf Master cycler gradient, Hamburg, Germany) programmed for one step of initial denaturation at $94^{\circ}$ for 2 min and 35 cycles of denaturation at $94^{\circ} \mathrm{C}$ for $1 \mathrm{~min}$, annealing at $55^{\circ} \mathrm{C}$ for $2 \mathrm{~min}$ for primers MYMV-CP-F/MYMV-CP-R and extension at $72^{\circ} \mathrm{C}$ for $3 \mathrm{~min}$, followed by one step of final extension at $72^{\circ} \mathrm{C}$ for $10 \mathrm{~min}$. PCR was conducted with Dream Taq Master mix (Fermentas) in total reaction mixture volume of $25 \mu$ l that contained Dream Taq Master mix- $13 \mu$ l; $\mathrm{dH} 2 \mathrm{O}-4 \mu \mathrm{l}$; forward and reverse primers
(20 pmole/ $\mu \mathrm{l})-2 \mu \mathrm{l}$ each; DNA template (total nucleic acid-100ng/ $\mu \mathrm{l})-4 \mu \mathrm{l}$, and PCR products were subjected to electrophoresis in $1 \%$ agarose at $50 \mathrm{~V}$ for 45 minutes in Electrophoresis system - SCOTLAB (Anachem Ltd.) in Tris-acetateEDTA buffer containing ethidium bromide @ $0.1 \%$. The gel was observed under Gel Documentation System (IMAGO Compact Imaging System, B \& L Systems, Isogen Life science, The Netherlands).

\section{Cloning and sequencing of coat protein gene of YMV infecting mungbean}

The PCR products were purified from agarose gel using Qiagen Gel Extraction kit (Qiagen, Hilder, Germany). All amplicons were cloned into the plasmid vector PTZ57R/T using InsTAclone ${ }^{T M}$ PCR Cloning Kit following the manufacturer's instructions. Transformed colonies were screened and selected on LB agar medium amended with ampicillin, X-gal and IPTG. Isolated plasmids from transformed positive clones were confirmed for the presence of insert using the respective $\mathrm{CP}$ specific primers. The resultant positive clones were fully sequenced in both directions using universal M13 forward and reverse primers. Full length sequence of coat protein of YMV was obtained by aligning of forward and reverse reaction sequences.

Phylogenetic analysis, nucleotide sequence and amino acid sequence comparison of coat protein gene of yellow mosaic virus of mungbean with other Gemini viruses

Pair wise and multiple sequence alignment of the full length of coat protein sequence of various YMV was done using MEGA 5.1 multiple alignment tool. The phylogenetic neighbor-joining trees and evolutionary analysis were conducted using MEGA 5.1 software package based on coat protein gene sequences of MYMV with 21 other Gemini virus sequences downloaded from NCBI Genbank [Table-1] [27]. Robustness of trees was determined by bootstrap sampling of multiple sequence alignment with 1000 replications. Comparison of the nucleotide and amino acid sequences of YMV was analysed by using sequence identity matrix tool of Bio-Edit software (Version 7.9.1).

\section{Results and Discussion}

The total nucleic acid was extracted from the leaves of mungbean with characteristic yellow mosaic symptoms using modified CTAB protocol. Primers used for the detection of MYMV were MYMV-CP-F/MYMV-CP-R corresponding to coat protein gene. The total DNA isolated from infected samples was used for PCR amplification. Polymerase chain reaction was employed to establish association of begomovirus through amplification of Gemini virus specific PCR product. Various dilutions 1:10 to 1:40 were prepared and subjected to PCR. The PCR results indicated that the virus could be detected from 1:20 to 1:40 dilutions. Virus specific DNA fragments of approximately 1000 bp were obtained from DNA of mungbean yellow mosaic infected samples, whereas no PCR product was obtained from DNA extracted from healthy samples and water control. PCR was performed in Thermocycler programmed for one step of initial denaturation at $94^{\circ}$ $\mathrm{C}$ for $2 \mathrm{~min}$ and 35 cycles of denaturation at $94^{\circ} \mathrm{C}$ for $1 \mathrm{~min}$, annealing at $55^{\circ} \mathrm{C}$ for $2 \mathrm{~min}$ and extension at $72^{\circ} \mathrm{C}$ for $3 \mathrm{~min}$, followed by one step of final extension at $72^{\circ} \mathrm{C}$ for $10 \mathrm{~min}$. An annealing temperature of $55^{\circ} \mathrm{C}$ for $2 \mathrm{~min}$ was found suitable for amplification of coat protein gene of mungbean yellow mosaic virus. PCR products were subjected to electrophoresis in $1 \%$ agarose. The gel was observed under Gel Documentation System.

Detection of yellow mosaic virus infecting mungbean was employed by PCR assays. Primers specific to MYMV (MYMV-CP-F/MYMV-CP-R) corresponding to coat protein gene were used. An expected band size of approximately $\sim 1000 \mathrm{bp}$ was amplified from MYMV-CP-F/MYMV-CP-R primers, designed specifically for MYMV but not from healthy plants [Plate-2]. Different authors have used different set of primers which were designed to amplify coat protein region of different legume yellow mosaic viruses [26, 28-32]. The amplicons obtained were electrophoresed through $1 \%$ agarose gel in $1 \mathrm{X}$ TAE and bands were visualized under UV light after staining with ethidium bromide $(0.05 \mu \mathrm{g} / \mathrm{ml})$. The bands were later excised from the gel and eluted through Qiagen gel extraction kit and cloned into plasmid vector $\mathrm{PTZ57R/T}$ using the PCR cloning kit following the manufacturer's instructions. Plasmid purification was carried out 
using a Qiagen plasmid miniprep kit. The insert was sequenced, assembled and its total length was found to be $889 \mathrm{bp}$. The actual length of Mungbean yellow mosaic virus isolate of Bangalore was $889 \mathrm{bp}$ including $115 \mathrm{bp}$ pre-coat protein at 5 ' end and 774 bp core coat protein. The length of deduced amino acid was 257.

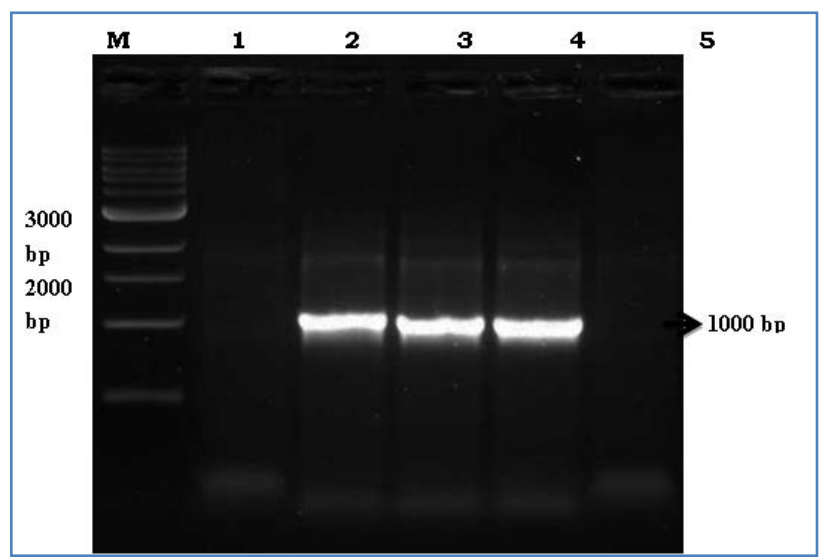

Plate-2 Amplification of coat protein gene of YMV infecting mungbean using MYMV-CP-F/MYMV-CP-R primer pair

Lane:

M- 1Kb Marker (NEB $1 \mathrm{~kb}$ DNA ladder)
Lane 1 - Healthy mungbean plant DNA

Lane 2, 3, 4 - Specific PCR product of 1000 bp from MYMV infected sample Lane 5 - Water control

The phylogenetic analysis of the coat protein sequence of yellow mosaic virus infecting mungbean was carried out together with the known begomoviruses sequences obtained from GenBank database. Gen Bank accession numbers of different begomoviruses used for MYMV-Bangalore isolate sequence comparison and phylogenetic analysis were presented in [Table-1].

Phylogentic tree based on alignment of coding nucleotide sequences of majority of Mungbean yellow mosaic viruses and Mungbean yellow mosaic India viruses showed two clusters with Mungbean yellow mosaic India virus(MYMIV) isolates falling in cluster I and Mungbean yellow mosaic virus(MYMV) isolates in cluster II [Fig-1]. Cluster phylogram based comparison of the coding nucleotide sequences of MYMV-Hebbal-Bangalore isolate revealed that the MYMV-Hebbal, Bangalore isolate group with cluster II. The present isolate clustered with MYMV-Nammakal, MYMV-Madurai, MYMV-Maharashtra and MYMV-Tamil Nadu isolates infecting moth bean, soybean, soybean and mungbean, respectively. The cluster phylogram based on multiple alignment of the nucleotide sequence of the $\mathrm{CP}$ gene of 10 isolates of MYMIV indicated that all the 10 isolates belonged to MYMIV as they formed cluster with other known isolates of MYMIV [32]

\begin{tabular}{|c|c|c|c|c|c|}
\hline SI. No. & Virus species & Abbreviation & Geographical origin & Host species & Accession number \\
\hline 1. & Mungbean yellow mosaic virus & MYMV-Haryana:MB & Haryana & Mungbean(MB) & AY271896.1 \\
\hline 2. & Mungbean yellow mosaic virus & MYMV-Namakkal:MoB & Namakkal & Mothbean(MoB) & DQ865201.1 \\
\hline 3. & Mungbean yellow mosaic virus & MYMV:Combodia:MB & Combodia & Mungbean(MB) & AY271892.1 \\
\hline 4. & Mungbean yellow mosaic virus & MYMV-Madurai:SB & Madurai & Soybean (SB) & AJ421642.1 \\
\hline 5. & Mungbean yellow mosaic virus & MYMV-Pakistan:SB & Pakistan & Soybean(SB) & AY269991.1 \\
\hline 6. & Mungbean yellow mosaic virus & MYMV-Maharashtra:SB & Maharashtra & Soybean(SB) & AF314530.1 \\
\hline 7. & Mungbean yellow mosaic virus & MYMV-Thailand:MB & Thailand & Mungbean(MB) & $\mathrm{AB} 017341.1$ \\
\hline 8. & Mungbean yellow mosaic virus & MYMV-Tamil Nadu:MB & Tamil Nadu & Mungbean(MB) & AJ132575.1 \\
\hline 9. & Mungbean yellow mosaic India virus & MYMIV-Indonesia:SB & Indonesia & Soybean(SB) & JN368438.1 \\
\hline 10. & Mungbean yellow mosaic India virus & MYMIV-Akola:MB & Akola & Mungbean(MB) & AY271893.1 \\
\hline 11. & Mungbean yellow mosaic India virus & MYMIV-India:SB & India & Soybean(SB) & AY049772.1 \\
\hline 12. & Mungbean yellow mosaic India virus & MYMIV-Indonesia:YLB & Indonesia & Yard long bean (YLB) & JN368437.1 \\
\hline 13. & Mungbean yellow mosaic India virus & MYMIV-Pakistan:BG & Pakistan & Blackgram(BG) & FM208845.1 \\
\hline 14. & Mungbean yellow mosaic India virus & MYMIV-Pakistan:MB & Pakistan & Mungbean(MB) & AY269992.1 \\
\hline 15. & Mungbean yellow mosaic India virus & MYMIV-Indonesia:YLB & Indonesia & Yard long bean (YLB) & JN368434.1 \\
\hline 16. & Mungbean yellow mosaic India virus & MYMIV-Indonesia:YLB & Indonesia & Yard long bean (YLB) & JN368432.1 \\
\hline 17. & Mungbean yellow mosaic India virus & MYMIV-Nepal:MB & Nepal & Mungbean(MB) & AY271895.1 \\
\hline 18. & Mungbean yellow mosaic India virus & MYMIV-Varanasi:Do & Varanasi & Fieldbean(Do) & AY547317.1 \\
\hline 19. & Mungbean yellow mosaic India virus & MYMIV-Bangladesh:MB & Bangladesh & Mungbean(MB) & AF314145.1 \\
\hline 20. & Mungbean yellow mosaic India virus & MYMIV-Jabalpur:SB & Jabalpur & Soybean(SB) & AJ416349.1 \\
\hline 21. & Mungbean yellow mosaic India virus & MYMIV-Palampur:FB & Palampur & Frenchbean (FB) & FN794200.1 \\
\hline
\end{tabular}

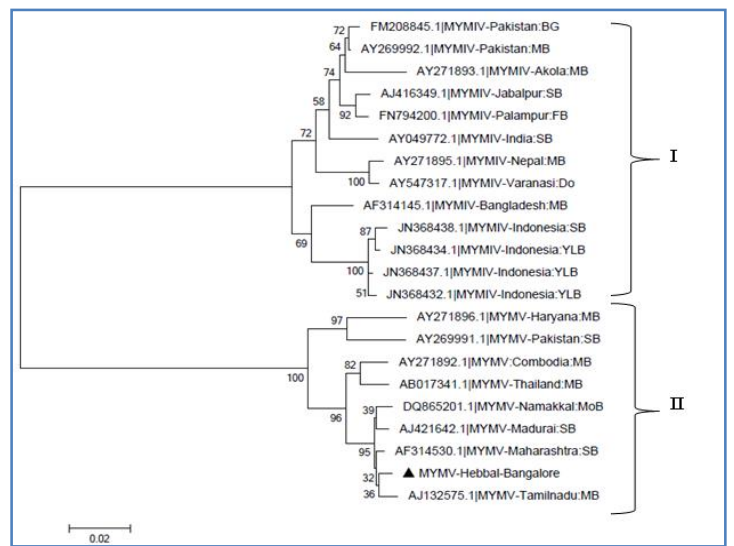

Fig-1 Phylogenetic tree obtained from comparision of complete nucleotide sequence of coat protein gene of MYMV with other geminiviruses from database. The dendrograms are calculated using neighbor-joining algorithm of MEGA 5.1 version. Numbers at nodes indicate percentage bootstrap confidence scores (1,000 replications).
Analysis of nucleotide sequence of coat protein gene of yellow mosaic virus associated with mungbean showed maximum identity of 99 per cent with MYMVMaharashtra:SB [AF314530.1], followed by 98.9 per cent with MYMV-Namakkal: MoB [DQ865201.1] as well as MYMV-Tamil Nadu:MB [AJ132575.1] and 98.8 per cent with MYMV-Madurai:SB [AJ421642.1] isolates. The identity of MYMV-Hebbal isolate with other MYMV isolates ranged between 94.5-99 percent. MYMV-Hebbal, Bangalore isolate showed an identity of 79.3-81.0 per cent with different MYMIV isolates [Table-2]. Analysis of CP gene sequences of isolates from mungbean and urdbean genotypes revealed these isolates had 95-99 per cent similarity at nucleotide level with known MYMIV isolates [32].

The amino acid sequence of mungbean yellow mosaic virus shared maximum identity of about 100 per cent with MYMV-Maharashtra:SB [AF314530.1], MYMVTamil Nadu:MB [AJ132575.1], 99.6 per cent with MYMV-Namakkal:MoB [DQ865201.1] and 99.2 per cent with MYMV-Madurai:SB [AJ421642.1]. The deduced amino acid identity of MYMV-Hebbal-Bangalore isolate with other MYMV isolates ranged between 96.4-100 per cent. The amino acid identity of MYMVHebbal-Bangalore isolate with other MYMIV isolates ranged from 84.0-85.9 per cent [Table-2]. Analysis of CP gene sequences of isolates from mungbean and urdbean genotypes revealed that these isolates had $96-100$ per cent similarity at 
amino acid level with known MYMIV isolates [32]. The above results revealed that yellow mosaic virus infecting mungbean from Hebbal, Bangalore is a Mungbean yellow mosaic virus but not Mungbean yellow mosaic India virus and is a variant of Mungbean yellow mosaic virus. The results obtained are in agreement with earlier investigations carried out by some other authors [26, 28, 30-33].

Table-2 Nucleotide and amino acid sequence identities of coat protein gene of yellow mosaic virus infecting greengram with other geminiviruses

\begin{tabular}{|c|c|c|c|c|}
\hline $\begin{array}{l}\text { SI. } \\
\text { No. }\end{array}$ & $\begin{array}{c}\text { Accession } \\
\text { number }\end{array}$ & Sequences & $\begin{array}{l}\text { Nucleotide } \\
\text { sequence } \\
\text { identity }\end{array}$ & $\begin{array}{l}\text { Amino acid } \\
\text { sequence } \\
\text { identity }\end{array}$ \\
\hline 1. & AY271896.1 & MYMV-Haryana:MB & 94.5 & 96.4 \\
\hline 2. & DQ865201.1 & MYMV-Namakkal:MoB & 98.9 & 99.6 \\
\hline 3. & AY271892.1 & MYMV:Combodia:MB & 97.1 & 98.0 \\
\hline 4. & AJ421642.1 & MYMV-Madurai:SB & 98.8 & 99.2 \\
\hline 5. & AY269991.1 & MYMV-Pakistan:SB & 95.0 & 97.2 \\
\hline 6. & AF314530.1 & MYMV-Maharashtra:SB & 99.0 & 100 \\
\hline 7. & $\mathrm{AB} 017341.1$ & MYMV-Thailand:MB & 97.4 & 98.8 \\
\hline 8. & AJ132575.1 & MYMV-Tamilnadu:MB & 98.9 & 100 \\
\hline 9. & JN368438.1 & MYMIV-Indonesia:SB & 79.9 & 84.0 \\
\hline 10. & AY271893.1 & MYMIV-Akola:MB & 79.3 & 84.4 \\
\hline 11. & AY049772.1 & MYMIV-India:SB & 81.0 & 85.6 \\
\hline 12. & JN368437.1 & MYMIV-Indonesia:YLB & 80.1 & 85.2 \\
\hline 13. & FM208845.1 & MYMIV-Pakistan:BG & 80.1 & 85.6 \\
\hline 14. & AY269992.1 & MYMIV-Pakistan:MB & 80.2 & 85.9 \\
\hline 15. & JN368434.1 & MYMIV-Indonesia:YLB & 79.9 & 84.4 \\
\hline 16. & JN368432.1 & MYMIV-Indonesia:YLB & 79.9 & 84.8 \\
\hline 17. & AY271895.1 & MYMIV-Nepal:MB & 79.5 & 85.2 \\
\hline 18. & AY547317.1 & MYMIV-Varanasi:Do & 79.5 & 85.6 \\
\hline 19. & AF314145.1 & MYMIV-Bangladesh:MB & 80.1 & 84.0 \\
\hline 20. & AJ416349.1 & MYMIV-Jabalpur:SB & 79.8 & 85.9 \\
\hline 21. & FN794200.1 & MYMIV-Palampur:FB & 79.8 & 85.9 \\
\hline
\end{tabular}

\section{Conclusions}

Mungbean is affected by both Mungbean Yellow Mosaic Virus (MYMV) and Mungbean Yellow Mosaic India Virus (MYMIV) according to earlier reports whereas our study reports the infection of MYMV on Mungbean from Karnataka. The CP gene is the most highly conserved gene in the family Geminiviridae. The $\mathrm{CP}$ sequence effectively predicts discrete strains, species and taxonomic lineage of begomoviruses. The International Committee on Taxonomy of Viruses (ICTV) accepts the classification of begomoviruses based on CP gene sequences. Member of the genus begomovirus are known to form clusters according to geographical origin. The results of the phylogenetic analysis, nucleotide sequence comparison and amino acid sequence comparison revealed that coat protein gene of yellow mosaic virus infecting green gram (MYMV-Hebbal-Bangalore) is a Mungbean yellow mosaic virus (MYMV) but not Mungbean yellow mosaic India (MYMIV) virus and it is a variant of mungbean yellow mosaic virus since it showed 94.5-99 per cent identity at nucleotide level with other MYMV isolates.

\section{Application of research}

The results of the present study help in devising effective management strategies against MYMV by developing transgenics based on coat protein or gene silencing approaches.

\section{Research Category: Agriculture/Plant Pathology/Plant Virology}

\section{Abbreviations}

MYMV-Mungbean yellow mosaic virus

MYMIV-Mungbean yellow mosaic India virus

CP-Coat protein

PCR-Polymerase chain reaction

\section{Acknowledgements}

First author thankfully acknowledges Department of Science and Technology (DST), New Delhi for providing financial assistance for research through Inspire Fellowship.
*Principle Investigator: Dr Rangaswamy K.T.

University: University of Agricultural Sciences, GKVK, Bangalore, 560065

Research project name or number: NIL

Author Contributions: All author equally contributed

Author statement: All authors read, agree and approved the final manuscript

Conflict of Interest: None declared

Ethical approval: This article does not contain any studies with human participants or animals performed by any of the authors.

\section{References}

[1] Nair R. M., Yang R. Y., Easdown W. J., Thavaraiah D., Thavaraiah P. and Hughes J. d.'A. (2013) Journal of the Science of Food and Agriculture, 93, 1805-1813.

[2] Anonymous (2012) Selected state wise Area, Production and Productivity of Moong (Kharif and Rabi) in India, Ministry of Agriculture and Farmers Welfare. Govt. of India.

[3] Bos L. (1999) Plant Viruses: Unique and Intriguing Pathogens: A Text Book of Plant Virology, Backhuys Publishers, The Nether-lands, 305-306.

[4] Nair N.G. and Nene Y.L. (1973) Indian Journal of Farm Science, 1, 109110.

[5] Roger Hull (2004) Mathew's Plant Virology, 4th ed., Elsevier Pub-lishers, India, 180-182.

[6] Nariani T.K. (1960) Indian Phytopathology, 13, 24-29.

[7] Manjunath B., Jayaram N., Muniyappa V. and Prameela H. A. (2013) Legume Res., 36(1), 62-66.

[8] Malathi V. G. and John P. (2008) Gemini viruses infecting legumes. In: G. P. Rao, P. L. Kumar, and R. J. Holguin-Peña (Eds.), Vegetable and pulse crops: Vol. 3. Characterization, diagnosis and management of plant viruses (pp. 97-123). USA: Studium Press LLC.

[9] Nene Y.L. (1973) Plant Disease Reporter, 57, 463-467.

[10] Dhingra K.L. and Chenulu, V.V. (1985) Indian Phytopathology, 38, $248-251$.

[11] Capoor S.P. and Varma P.M., (1950a) Current Science, 19: 248-249.

[12] Chenulu V.V. and Verma A. (1988) Virus and virus like diseases of pulse crops commonly grown in India. In: Pulse Crops, Eds. Baldev, B., Ramanujam, S. and Jain, H.K., Oxford and IBH Publishing Co., New Delhi, pp.338-370.

[13] Chenulu V.V., Venkateswarlu V. and Rangaraju R. (1979) Indian Phytopathology, 32, 230-235.

[14] Deepa H., Govindappa M.R., Sunil Kulakarni Kenganal M. and Biradar S.A. (2017) Int. J. Curr. Microbiol. App. Sci., 6(10), 678-684.

[15] Ahmed M. and Harwood R.F. (1973) Plant Disease Reporter, 57: 800-802.

[16] Jayappa, Ramappa H. K., Jabbar Sab and Devamani B. D. (2017) Int. J. Pure App Biosci., 5 (3), 238-244.

[17] Murugesan S. and Chelliah S. (1977) Madras Agricultural Journal, 64(2), 128-130.

[18] Nath P.D. (1994) Annals of Agricultural Research, 15(2), 174-177.

[19] Pathak A.K. and Jhamaria S.L. (2004) Journal of Mycology and Plant Pathology, 34(1), 64-65.

[20] Peerajade D.A., Ravikumar R.L. and Rao M.S.L. (2004) Indian Journal of Pulses Research, 17(2), 190-191.

[21] Rathi Y.P.S. and Nene Y.L. (1974a) Indian Phytopathology, 27, 459-462.

[22] Rathi Y.P.S. and Nene Y.L., (1974b) Acta Botanica Indica, 2, 74-76.

[23] Rathi Y.P.S. and Nene Y.L. (1976) Pantnagar Journal of Research, 1, 107111.

[24] Shaik Abdul Salam (2005) Studies on mungbean yellow mosaic virus disease on greengram. M.Sc. (Agri.) Thesis, Univ. Agric. Sci, Dharwad, 75. 
[25] Rouhibakhsh A., Priya J., Periasamy A., Haq Q. M. I. and Malathi V. G. (2008)J. Virological Methods, 147, 37-42.

[26] Naimuddin and Mohd. Akram (2010) J. Food Legumes, 23, 191-195.

[27] Tamura K., Dudley J., Nei M. and Kumar S. (2007) Mol. Biol. Evol., 24, 1596-1599.

[28] Obaiah S. (2011) Molecular detection and characterization of yellow mosaic virus infecting blackgram in Andhra Pradesh. M. Sc. (Agri.) Thesis, Acharya N.G. Ranga Agri. Univ., Hyderabad, 99pp.

[29] Naimuddin, Mohd. Akram, Aditya Pratap, Brijesh Kumar Chaubey and Joseph K. John (2011) J. Food Legumes, 24, 14-17.

[30] Kamaal Naimuddin, Mohammad Akram and Gupta Sanjeev (2011) Phytopathol. Mediterr., 50, 94-100.

[31] Mohammad Nurul Islam, Sonia Khan Sony and Rita Sarah Borna (2012) PI. Tissue Cult. Biotech., 22, 73-81.

[32] Naimuddin and Akram M. (2012) J. Food Legume, 25, 286-290.

[33] Sachan Mansi, Mishra Minakshi, Naimuddin and Akram Mohd. (2010) Trends Biosci., 3, 166-168. 